\title{
SOUTH AFRICA'S ECONOMIC POLICIES ON UNEMPLOYMENT: A HISTORICAL ANALYSIS OF TWO DECADES OF TRANSITION
}

\author{
Lorainne Ferreira* \\ North-West University
}

Received: April 2016

\author{
Riaan Rossouw* \\ North-West University
}

Accepted: July 2016

\begin{abstract}
Upon South Africa's transition to democracy in 1994, there were great hopes for an economic revival in the country, underpinned by supportive economic policies that prioritised job creation and the elimination of longstanding poverty and inequality. Until now, the efficacy of economic policy in bringing about these much-coveted outcomes - particularly improvements on the employment front has received little attention. This paper ventures into relatively uncharted territory by analysing how political dynamics and accompanying economic policy frameworks have impacted the structure and momentum of employment growth in South Africa over the past two decades. This is achieved by examining the changes in employment and, more specifically, the changes in the cost-neutral change in the capital-to-labour (K/L) ratio from 1995 to 2013. For the purpose of the analysis, a dynamic CGE model of the South African economy is used, with the focus being primarily on changes in the capital and labour markets during the period in question across a range of sectors. Among the results are that there was an increase in capital relative to labour (K/L) during the period, despite there being an increase in the rental price of capital relative to wages $\left(\mathrm{P}_{K} / \mathrm{P}_{\mathrm{L}}\right)$. The results suggest that at any given ratio of real wages relative to the rental price of capital, industries would choose a $\mathrm{K} / \mathrm{L}$ ratio $8.1 \%$ higher in 2013 than in 1995. The study offers new insights into what is hampering employment in South Africa, which has been eroding the economy's productive base and prompting serious questions about the country's growth prospects. Clearly, South Africa needs a well-informed and responsive economic policy framework if it is to escape the potentially explosive unemployment crisis in which it has long been mired.
\end{abstract}

Keywords

Economic policy, South Africa, unemployment, CGE modelling, capital-to-labour ratio

\footnotetext{
*Ms L Ferreira is a researcher at the TRADE research focus area, North-West University, South Africa [Lorainne.Steenkamp@nwu.ac.za].

\#Prof R Rossouw is a researcher TRADE research focus area, North-West University, South Africa.
} 


\section{INTRODUCTION}

South Africa crossed the threshold into a new, democratic era more than two decades ago - a sufficiently long time ago to warrant serious reflection on the country's growth performance in the intervening period and the role that economic policy has played in the process. Since 1994, a succession of economic policies has been introduced by the government in a bid to restore South Africa's macroeconomic stability, position the country as a global and regional trade partner, and attract foreign capital. While these economic policies have, to a greater or lesser extent, inevitably had an impact on South Africa's productive capacity, market structure, competitiveness and economic growth trajectory, it is invariably job creation that has been at the core of the government's strategic economic policy making and planning.

The course of events over the past two decades serves as a reminder that South Africa's challenges did not end with the transfer of political power. One of the most telling remnants of the apartheid era was a dislocated society, with large numbers of non-white South Africans having been denied access to decent education, living standards and employment opportunities. A key imperative, therefore, in the years following 1994 was to seriously address the pervasive inequality and poverty in the country by adopting strategies that prioritised job creation. This process has been far from smooth, however, with a myriad of internal and external factors conspiring to complicate and at times retard South Africa's socio-economic recovery.

Today, South Africa still faces the formidable challenge of taking its economy into a technologically advanced future, while ensuring that its marginalised communities are not left behind on the road to sustainable economic growth and development (Burger \& Woolard, 2005). This paper takes stock of the extent to which economic policies have been a catalyst for positive change in South Africa over the past two decades - particularly in terms of building human capital and making a meaningful dent in unemployment - thus providing a useful foundation for future policy making and strategy formulation.

The rest of this paper is organised as follows: section 2 provides a literature overview of the dynamics of South Africa's labour market and accompanying policy environment. Section 3 outlines the research methodology used in a historical analysis covering the period 1995 to 2013. Section 4 summarises and explains the results of the analysis, and section 5 makes a number of final observations.

\section{LITERATURE REVIEW}

South Africa's transition to democracy in 1994 created expectations of a marked turnaround from the economic decline that was being experienced under apartheid. It also fuelled hopes of greater socio-economic wellbeing, together with reduced inequality (Aron, Kahn \& Kingdon, 2008). To foster economic growth and support redistribution, sound macroeconomic policies were expected to be implemented. In particular, it was hoped that there would be improved access to education and training, and thus employment opportunities, which would help to tackle poverty (Aron et al., 2008). However, as the literature review will show, this optimism has been diluted by a range of adverse factors and developments. 


\subsection{Constraints to growth and employment creation}

The reasons for South Africa's high unemployment rate are numerous and diverse. Researchers such as Lingens (2003), and Herwartz and Niebuhr (2011), point out that an overriding factor influencing employment, in the long run, is economic growth. In 2011, Herwartz and Niebuhr developed an econometric model to study the link between unemployment and growth. They used Okun's law as a starting point, which is an empirically observed relationship between losses in production and unemployment in a country. Using Okun's law, they found that the relationship between unemployment and growth is determined by the labour market structure and framework. In an earlier study, and in support of the work of Herwartz and Niebuhr (2011), Lingens (2003) developed a model based on the relationship between unemployment and growth. He found that it was possible to have either a positive or negative correlation between the two variables, depending on the value of the elasticity of substitution between high-and low-skilled workers.

Over the past decade, much attention has been given to identifying the constraints to growth in South Africa. While various studies have produced recommendations for change at the macroeconomic level, specifically in respect of fiscal and monetary policy, others have placed more emphasis on microeconomic and structural reforms in the areas of, for example, education, skills development, industrial policy, labour market policy and black empowerment. Such reforms, they assert, would help to stimulate higher levels of growth, which, in turn, would pave the way for higher employment.

To some extent, the low levels of growth and employment witnessed in South Africa over the years are a reflection of a skills mismatch in the economy. According to Bosworth and Collins (2003), the structure of the economy has evolved in response to technological advances and the changing demands of production, together with the growing need for higher-level skills. Furthermore, Fields and Kanbur (2007) indicate that the inherent preference for higher-level skills, together with the growth of a young and relatively well-educated workforce, has resulted in a sharp rise in unemployment since 1994.

Banerjee, Galiani, Levinsohn, McLaren and Woolard (2008) refer to sectoral changes in unemployment, attributable to structural shifts in production from the employment-intensive primary sector to the tertiary or services sector. This has prompted a decrease in the demand for labour, particularly unskilled labour. Banerjee et al. (2008) further emphasise that because of the structural nature of South Africa's unemployment (which has resulted in even skilled sectors in the country finding it difficult to fill certain positions), the unemployment phenomenon is unlikely to improve without policy interventions.

Available evidence from Statistics South Africa's (Statistics South Africa, 1995, 2002) Labour Force Survey (LFS) and Household Survey indicates that from 1995 to 2002, South Africa experienced a particularly high rate of unemployment growth. In fact, during this period, the growth in unemployment was significantly higher than the growth in the working age population (Burger \& Woolard, 2005).

In addition, the rising cost of labour and labour market rigidities have been posited as causes of rising unemployment. According to Fedderke and Bogetic (2006), structural changes in the economy, combined with labour militancy, favour skilled workers, which leads to rising labour costs that exceed labour productivity improvements. Sectors such as mining and agriculture, which have strongly negative elasticities of labour demand that typically rely on semi-skilled and unskilled labour, have been adversely affected by these trends. 
Moreover, South Africa has an abundant supply of low- and medium-skilled workers but relatively few highly-skilled workers, a situation that is aggravated by the ongoing emigration of skilled individuals. Introducing technological change across various sectors of the economy shifts the demand away from the labour pool that South Africa has in abundance. Aron et al. (2008) argue that South Africa's labour legislation is far too strict for a country with this type of unemployment climate. In this regard, they assert that the lack of flexibility in labour market legislation is actually exacerbating unemployment and inequality in economic circles.

Considering the magnitude of South Africa's unemployment problem and the fact that there is a large supply of low-skilled labour, one would expect the informal sector to be fairly large. However, in reality, the country's informal sector is relatively small by international standards. This anomaly might point to the existence of various barriers to entry into the informal sector.

\subsection{South Africa's informal sector and employment}

Given South Africa's growing workforce but dearth of formal employment opportunities, job seekers have turned more and more to the informal sector for employment. According to Adams, Da Silva and Razamard (2013), globalisation has been a major contributor to the growth of informal activities, while formal employment opportunities, in contrast, have been squeezed. In South Africa, the informal sector is characterised by the provision of a broad range of services, including food sales and other street vending, and miscellaneous repairs (Fox \& Sekkel, 2008).

Jobs in the services sector are characterised by a high degree of informality and are therefore vulnerable. Yet despite the fact that South Africa's informal sector suffers from a propensity towards low wages, it presents numerous opportunities and, according to Staatz and Dembele (2007), is part of the solution to the unemployment problem. Unfortunately, according to Lavopa and Szirmai (2012), the government focuses more on creating jobs than on creating productive employment.

Maloney (2002) asserts that a lack of experience and capital are common barriers to entrepreneurship, which become truly prohibitive in the case of the unemployed. In support of the findings of Bhorat, Lundall and Rospabe (2002), Kingdon and Knight (2008) are of the opinion that small firms cannot afford the rising labour costs associated with rigid labour laws, and they are thus barred from taking up many entrepreneurial activities.

The phenomenon of rising unemployment among semi-skilled and unskilled workers presents something of a challenge for policy makers - particularly because sectors that became internationally competitive and showed strong growth during the 1990s did so by shedding lessskilled workers and increasing the capital and skill intensity of production. However, the shortage of skilled labour in the country will constrain the future growth of these sectors, assuming that the number of capital-intensive businesses will continue to grow, that there will be a shift in the demand for exports, and, furthermore, there will be changes in the rental price of capital and the cost of labour. Thus, the development of human resources, as a policy imperative, is crucial to addressing the unemployment problem among semi-skilled and unskilled workers as it will enable them to move from the informal sector to the formal sector.

According to Bell and Gattaneo (1997) and Bhorat and Hodge (1999), South Africa's growing unemployment problem can be attributed to globalisation and the increasing openness of the economy, which has led to shifts in the skill composition of labour demand. The unintended consequence has been a shift in industrial policy towards the creation of an economy that is more 
capital- and skill-intensive than labour-intensive, serving only to worsen structural unemployment.

\subsection{The impact of trade and trade liberalisation on employment}

When South Africa became a democracy in 1994, the intention was to encourage higher growth rates and create sufficient employment opportunities for the available pool of labour, thereby reversing the high unemployment levels that prevailed before 1994. A key objective was to restructure the manufacturing sector in order to make the economy more internationally competitive. Unfortunately, the results have not been impressive.

The country's industrial policy post-1994 initially succeeded in enhancing international competitiveness, as was evident in a substantial increase in manufactured exports. However, because international competitiveness requires the kind of technological change that is biased towards capital- and skill-intensive manufacturing, the sector's contribution to growth and employment creation has been disappointing (Du Plessis \& Smit, 2007). An analysis by Edwards (2001) of the factors that drive export growth and labour demand revealed that these factors go hand in hand with rising unemployment.

As a consequence of ongoing technological change and improvements, Edwards (2001) found that there was a significant rise in the capital intensity of exports from 1993 to 1997 , once again leaning towards skill intensity in the manufacturing sector.

Lewis (2002) agrees with Edwards that South Africa has a remarkably small and declining share of exports that mainly use unskilled labour, compared with the relatively large share of exports that use more skilled labour. This explains why despite the growth in exports, the manufacturing sector is still not creating jobs.

The Department of Trade and Industry (DTI) (2002) acknowledges the correlation between high levels of capital investment, skill-intensive technology and export-orientated industries, which together constitute an important foundation for international competitiveness. Trade liberalisation, in turn, has transformed the structure of the South African economy, altering the nature of the demand for labour and driving up unemployment.

Unless the pool of skilled workers increases rapidly, any further growth of manufactured exports will be constrained by skills shortages, producing even higher unemployment levels and larger numbers of despondent job seekers.

\subsection{Implications for labour demand}

Policy makers in government believe that the future of labour demand depends on South Africa's manufacturing sector and its potential for growth. However, unless the skills of the South African labour force are rapidly enhanced, the development path that government has chosen will be unattainable.

According to Altman and Mayer (2003), rising unemployment in South Africa can also be ascribed to the loss of jobs in the traditional resource-based industries of mining and agriculture without a simultaneous rise in employment in more advanced industrial sectors - as would be expected from a well-orchestrated development programme. Altman and Mayer (2003) attribute the loss of jobs in the primary resource-based industries to changing technical conditions and adverse 
commodity price trends (in the case of mining). In agriculture, the fear of potential land tenure claims and labour market laws and rigidities have suppressed labour demand.

Employment growth not only depends on economic growth, but also on the formation of a strong human capital base. According to Altman and Mayer (2003:80-81), South Africa has weak capabilities when it comes to human capital formation. In this regard, they see the slow growth of the secondary and tertiary sectors (due to restricted international interaction), limited small business activity, constrained demand and structural weaknesses in the labour market as being possible causes of the weak human capital base and dwindling employment prospects. The seeds of these conditions were sown before 1994 in an effort to boost import substitution, combat sanctions, and control the job market and access to education.

According to Banerjee et al. (2008), Adams et al. (2013) and Du Plessis and Smit (2007), the legacy of apartheid has left South Africa with a severe gap in skills attainment. Because of South Africa's sophisticated cost structure and domestic market production sectors, the country is considered to be a middle-income economy. However, Klasen and Woolard (2009) assert that the skills level of the country is more closely associated with that of a less-developed country.

In reality, the potential for mass employment through labour-intensive exports in a middleincome economy like South Africa is quite limited. According to Altman (2001), reliance on a labour-intensive export strategy is unrealistic in a middle-income economy since firms then need to have a policy of paying low wages in order to remain competitive.

Ultimately, the South African economy's ability to absorb more labour depends on the expansion of two joint activities: higher-value tradables and low-productivity, non-traded subsectors (Kapsos, 2005). In the past, economic thinking in South Africa tended to separate these two activities. On the one hand, the emphasis was on the importance of a stable macroeconomic environment, together with labour market flexibility, to boost the expansion of low-productivity tradables through Foreign Direct Investment (FDI). On the other hand, MERG (1993) pointed to state-financed opportunities, such as mass housing and public works programmes, as a way of increasing the demand for domestic labour. However, these approaches do not address the question of where the revenue will be obtained to finance the expansion of local labour demand. They also underestimate South Africa's structural constraints to achieving macroeconomic stability.

Altman (2001) and Kapsos (2005) both state that one of the most effective ways of creating employment opportunities is by increasing domestic demand for labour-absorbing, non-traded goods and services. Although most goods and services can be traded, some are orientated towards the local market, such as social services and construction.

Promoting non-traded goods and services, such as public works programmes and housing construction, is a recommended approach for boosting the economy and has long been seen as a Keynesian-type employment programme. Housing construction, in particular, is often seen as a feasible strategy for meeting the need for housing, while also providing the basis for small business development.

Most of South Africa's national growth policies that have been implemented since 1994 by the ANC government, such as the Redistribution and Development Programme (RDP), the Growth, Employment and Redistribution (GEAR) strategy, the Accelerated and Shared Growth Initiative of South Africa (ASGISA), and the New Growth Path (NGP), together with the Industrial Policy Action Plan (IPAP), have incorporated the jobs-through-construction strategy. 


\subsection{Policies to generate productive employment}

South Africa's acceptance back into the global economy after 1994 ramped up the pressure for the country to achieve economic stability and introduce economic policy reforms that addressed the critical challenges at the time. Initially, South Africa adopted an economic policy called the Reconstruction and Development Programme (RDP), which emphasised the importance of creating a strong, balanced and dynamic economy on the back of wide-ranging education and training opportunities, rising literacy levels and a dynamic youth sector. In reality, the RDP policy framework focused mainly on ways to tackle the lack of equity and poverty, with little emphasis being placed on fiscal constraints (Van der Berg, 2006). Although the RDP framework did not specify any particular numerical targets for growth and employment, debt ratios and fiscal deficits, it nevertheless required substantial resources and other policy initiatives that were not yet in place to ensure success. From the outset, the government lacked the capacity to implement such a policy.

This prompted a transition to the Growth, Employment and Redistribution (GEAR) strategy in 1996, which was aimed at producing an annual growth rate of at least $4.2 \%$ and creating 400000 new job opportunities per year. However, according to Visser (2004), the economy grew by a meagre $2.7 \%$ per year under GEAR's watch, instead of the optimistically envisaged $6 \%$. Also, more than a million jobs were lost between 1996 and 2001 , which was to have been the deadline for the creation of 1.3 million new employment opportunities (Hirsch, 2005). In the end, the GEAR strategy - which was accompanied by a cut in government expenditure without any corresponding measures to stimulate economic activity and job creation - actually restricted economic growth and was generally viewed as being unsuccessful (Visser, 2004).

While the GEAR strategy was in place, the government realised that an annual growth rate of $2.7 \%$ was not enough to address the entrenched and intertwined legacies of unemployment and poverty. The government therefore implemented the Accelerated and Shared Growth Initiative of South Africa (ASGISA) in 2006, the aim of which was to halve poverty and unemployment by 2014 and achieve a $6 \%$ annual growth rate by 2010 (ASGISA, 2006). Under ASGISA, the country experienced four consecutive years of positive growth, which led to investment growth of more than $20 \%$. Given this positive growth and investment climate, some jobs were created, as evidenced in the fact that unemployment declined from $27.9 \%$ in 2004 to $20.7 \%$ in 2008 (Statistics South Africa, 2011). However, due to the negative impact of the global financial crisis of $2008 / 2009$, unemployment rose again to $25.7 \%$ by the end of 2009 (Statistics South Africa, 2011).

In the wake of the global financial crisis, South Africa - like many other countries - was pitched into a recession. The introduction of the New Growth Path (NGP) in 2010 as a successor to ASGISA was the government's response to the economic stagnation that had gripped the country. Similar to ASGISA, the NGP (which prevails to this day) places the emphasis on significant investment in social development, training and education, and aims to create five million jobs by 2020 (Economic Development Department, 2011). To achieve this, six key sectors were identified that showed particular promise for unlocking employment opportunities. Termed "job drivers", these sectors are: infrastructure development, manufacturing, mining value chain, agriculture, tourism and the green economy.

Despite the fanfare surrounding the launch of the NGP, this economic policy has so far fallen short in its quest to take South Africa forward. Firstly, the policy instruments of the NGP are no different from those that featured in the GEAR strategy. Secondly, the NGP has earned a reputation for being overly gentle when it comes to driving the envisaged new growth, and, thirdly, it does not 
have the necessary mechanisms in place to assess the socio-economic challenges that it is supposed to resolve.

Alongside the NGP, the fifth iteration of the Industrial Policy Action Plan (IPAP) was adopted in 2013, which sets out the government's broad approach to industrialisation. IPAP forms part of a larger set of interrelated strategies and policies, highlighting the fact that sectors have different characteristics and contribute to economic growth and job creation in their own unique ways (DTI, 2013). As it is essentially woven into all policy frameworks, IPAP has a strong role to play in boosting economic growth and employment in South Africa. Importantly, one of IPAP's aims is to promote more labour-absorbing industrialisation, which will help job creation and contribute to sustainable industrial development (DTI, 2013).

All of the policies discussed in this section have been informed by the need to tackle the negative consequences of apartheid, i.e. pervasive inequality, poverty and unemployment. However, studies show that these policies have largely been unsuccessful in this regard, as poverty and unemployment are on the rise while inequality continues to be widespread (0cran, 2009).

Furthermore, observable trends indicate that the South African economy has lost momentum over the past five years. The low growth and employment figures, especially when compared with the country's peers, are of particular concern to the government (Fourie, 2013). Firstly, with an increase of only $33 \%$ in average GDP per capita since 1994, South Africa lags far behind other emerging markets and developing countries, which have shown a mean increase of $115 \%$. Secondly, inequality remains a significant challenge, both for the South African government and citizens at large, since not all South Africans have shared equally in the rise in GDP per capita. Thirdly, unemployment has worsened since 1994, with the unemployment rate standing at approximately $24 \%$, or $40 \%$ if the broader definition is used (Statistics South Africa, 2013b).

While the economy is currently creating jobs, the supply is insufficient for the growing labour force. Therefore, the government's national policy framework should be making provision for more vigorous structural reforms aimed at facilitating high (and particularly inclusive) growth, and tackling unemployment and poverty in meaningful ways. For this to happen, the correlation between growth and employment needs to be fully unpacked and understood (Black, Calitz \& Steenekamp 2011).

\subsection{The South African labour market: 1994-2014}

The South African labour market has helped to define not only the economy but society as a whole. Before 1994, the labour market was divided along racial lines. This resulted in limited educational opportunities for non-whites, rendering them eligible for non-skilled and low-paying jobs only. Since 1994, however, various legislative changes have been implemented to address the wrongdoings of the past. These changes have delineated the rights of labourers, encouraging the employment of non-white workers, and prescribing minimum working conditions to reduce prior socially based inequalities.

Various studies have been conducted on South Africa's labour market and employment performance since 1994. The general findings of $\mathrm{Yu}$ (2008) and Hodge (2009) have been that South Africa's labour market has grown faster than the employment take-up and so not all new entrants have found employment. Furthermore, Burger and Woolard (2005) and Oosthuizen (2006) have found that economic growth in itself is not sufficient to reduce unemployment. In addition, $\mathrm{yu}_{\mathrm{u}}$ (2008) concludes that the segments of the population with low skill levels, i.e. those living in rural and underdeveloped areas, as well as non-whites, are most likely to be unemployed. 
A study recently conducted by Lyle, Kasongo, Moses and $\mathrm{yu}_{\mathrm{u}}$ (2015) revealed that unemployment remains one of South Africa's most serious challenges and listed a host of reasons for this. Firstly, an education system that does not produce properly educated workers translates into high numbers of uneducated youth entering the labour market with no skills. Secondly, wage rigidity due to new legislation (which dictates that minimum wages are above the market clearing level) makes it impossible for employers to employ all the labour they want to. Thirdly, there is the phenomenon of unrealistic reservation-level wages, where graduates are reluctant to work if their monthly income does not exceed their monthly income from social grants. Finally, South Africa has a small informal sector that is not easy to access. As a result, those who cannot find employment in the formal sector also struggle to become employed in the informal sector, mainly due to limited access to the credit market and a lack of infrastructure. In the face of these problems, the South African job landscape has not been able to absorb sufficient numbers of new participants, resulting in an overall increase in unemployment.

\subsubsection{Status of the working age population}

FIGURE 1 shows the status of South Africa's working age population from 1994 to 2013, highlighting the fact that since 1994, more and more people have been entering the labour market to actively seek employment, particularly in urban areas. As a result, the share of working age adults who were not employed or were looking for a job, known as the "economically inactive population", fell from $41 \%$ in 1994 to $37 \%$ in 2013 (Statistics South Africa, 2013c). In this regard, the number of people actively seeking work was estimated at 2.4 million in the mid-1990s, rising to 4.8 million in 2013 (Statistics South Africa, 2013c).

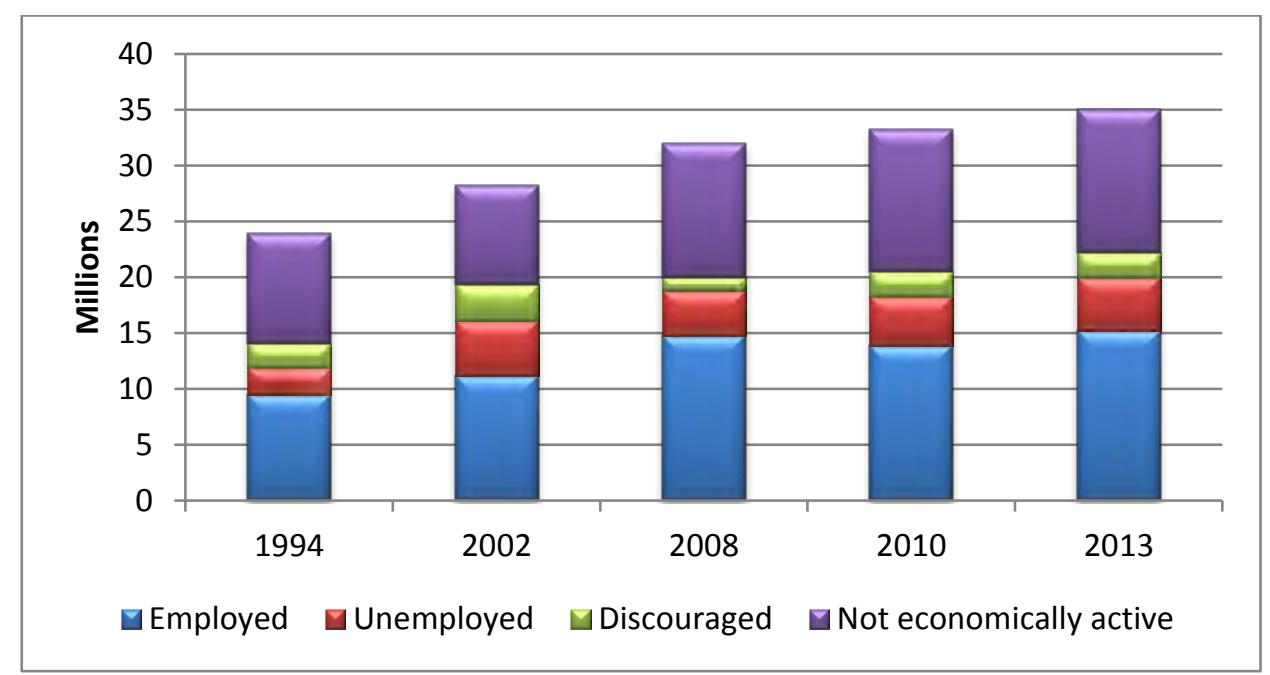

\section{FIGURE 1: Status of the working age population: 1994-2013}

Source: Statistics South Africa (2013c)

One of the government's biggest concerns is unemployment among the youth. In $1994,37 \%$ of the youth aged 18 to 29 were not employed or in training or receiving some sort of education, and this had risen to $44 \%$ by 2013 (Statistics South Africa, 2013d). The estimated unemployment rate among the youth aged 18 to 29 rose by $10 \%$ from 1994 to 2013 , boosting the number of unemployed youth by 1.3 million (Statistics South Africa, 2013c). 


\subsubsection{Employment overview of the different industries}

To better understand the structural shift in employment in South Africa, FIGURE 2 considers the percentage change in the growth of total employment by sector from 2001 to 2013.

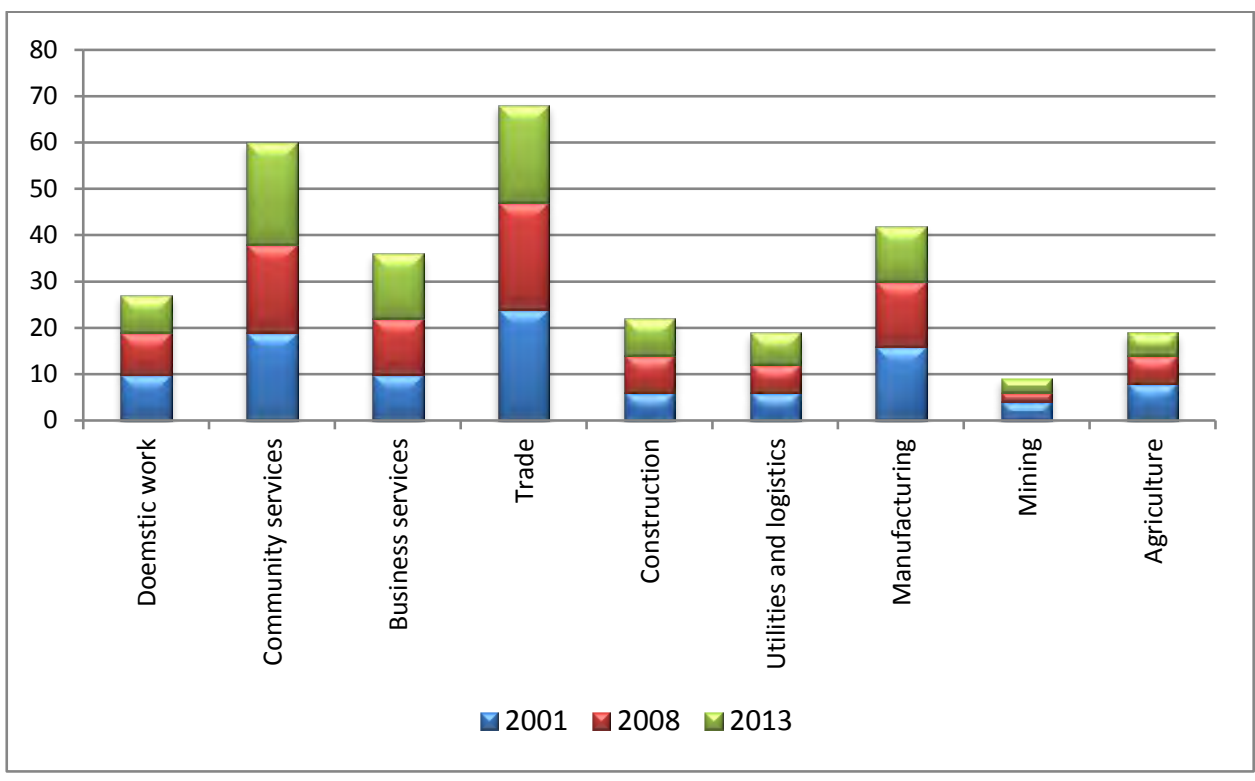

FIGURE 2: Employment by sector

\section{Source: $\quad$ Statistics South Africa (2013a)}

Note: The sectors shown in FIGURE 2 are the nine broad classifications used by Statistics South Africa and the South African Reserve Bank (SARB).

FIGURE 2 illustrates that a significant number of new job opportunities were created in the community services sector from 2001 to 2013. These opportunities were primarily in education, healthcare and the South African Police Service (Statistics South Africa, 2013a). The expansion of business services was the primary reason for employment growth in the private sector, together with growing employment in transport, communication and construction.

In contrast, main productive sectors such as manufacturing and mining experienced much slower growth in employment and accounted for a shrinking percentage of total employment over the same period. Similarly, domestic or household services, which are a major employer of African women, experienced some growth, but also fell as a percentage of total employment in the economy. More perturbing is the fact that the agricultural sector saw a decline in both job growth and its share of total employment from 2001 to 2012, despite showing some growth in 2013.

Changes in the trade sector have mostly been driven by internationalisation and consolidation, and an increase in competition. Some of these changes have transformed the way in which business operates and the types of jobs for which there is a demand (Van Aardt, Ligthelm \& Van Tonder, 2011). South Africa's wholesale and retail sector is regarded as a major employer and source of growth for the economy. However, to ensure the sector's competitiveness and its contribution to economic growth, there is an urgent need for skills development (Van Aardt et al., 2011). 
Owing to a substantial increase in government spending on labour-intensive projects, the community services sector has been ranked as the second-largest employment sector since 2001. These labour-intensive projects are collectively referred to as the Extended Public Works Programme (EPWP), which has two major components: using labour-intensive methods to create new job opportunities, and teaching people new skills to find jobs after completing the EPWP (NGP, 2010). The EPWP, though, does not represent sustainable job creation in the long term.

Finally, the business services sector has probably benefited the most from technological advances and has been the least disrupted by labour unrest, resulting in a sharp increase in employment (IMF, 2013). However, one of the reasons for the strong performance of the business services sector is the rise in debt levels (especially among households), which is not sustainable in the long run.

The rise of industries such as trade and manufacturing and their increasing contribution to growth reveal a shift in demand towards more skilled labour and capital-intensive production. The government's education and skills development policies need to take this into account since trends over the past two decades show rising unemployment among unskilled workers (Van Aardt et al., 2011).

FIGURE 3 presents a combined chart to illustrate the unemployment rate associated with the annual GDP growth rate and the average capital-to-labour ratio from 1994 to 2014. The figure is divided according to each key policy period to show the relationship between the different variables and how they changed as each new policy was implemented.

The structural changes across these various industries and the increasing demand for skilled labour is worrying for a country like South Africa, which is considered to be capital-poor and unable to manufacture heavy or specialised machinery and equipment on a profitable basis. Yet in recent years, South Africa has been experiencing an increase in the capital intensity of production. This is evident in FIGURE 4, which shows that from 2005 to 2014, the capital required to produce each unit of output increased. Ironically, this increase in the capital intensity of production is a mixed blessing for a country that has an abundant supply of labour. Some would argue that the trend should be towards labour-intensive production rather than capital-intensive production.

Until now, the debate about the efficacy of economic policy in South Africa has received little attention, particularly in how it has contributed to job creation. By analysing South Africa's political dynamics and accompanying economic trends, this paper sets out to determine how the structure and momentum of employment in South Africa have changed during the periods in which the various policies have been in place. Measuring the historical impact of these policies should go a long way in assisting decision makers to make better-informed decisions and to arrive at more responsive economic policies in the future.

\section{RESEARCH METHODOLOGY}

South Africa's unemployment problems have been well documented in the literature. This section quantifies some of the factors underlying the country's struggles in this regard, using historical CGE (Computable General Equilibrium) simulations. The primary aim is to provide some initial estimates of changes in a review of various economic policies in South Africa from 1995 to 2013, using the historical CGE modelling methodology introduced by Dixon and Rimmer (2002). The focus is primarily on changes in the capital and labour markets across all sectors over this period. 


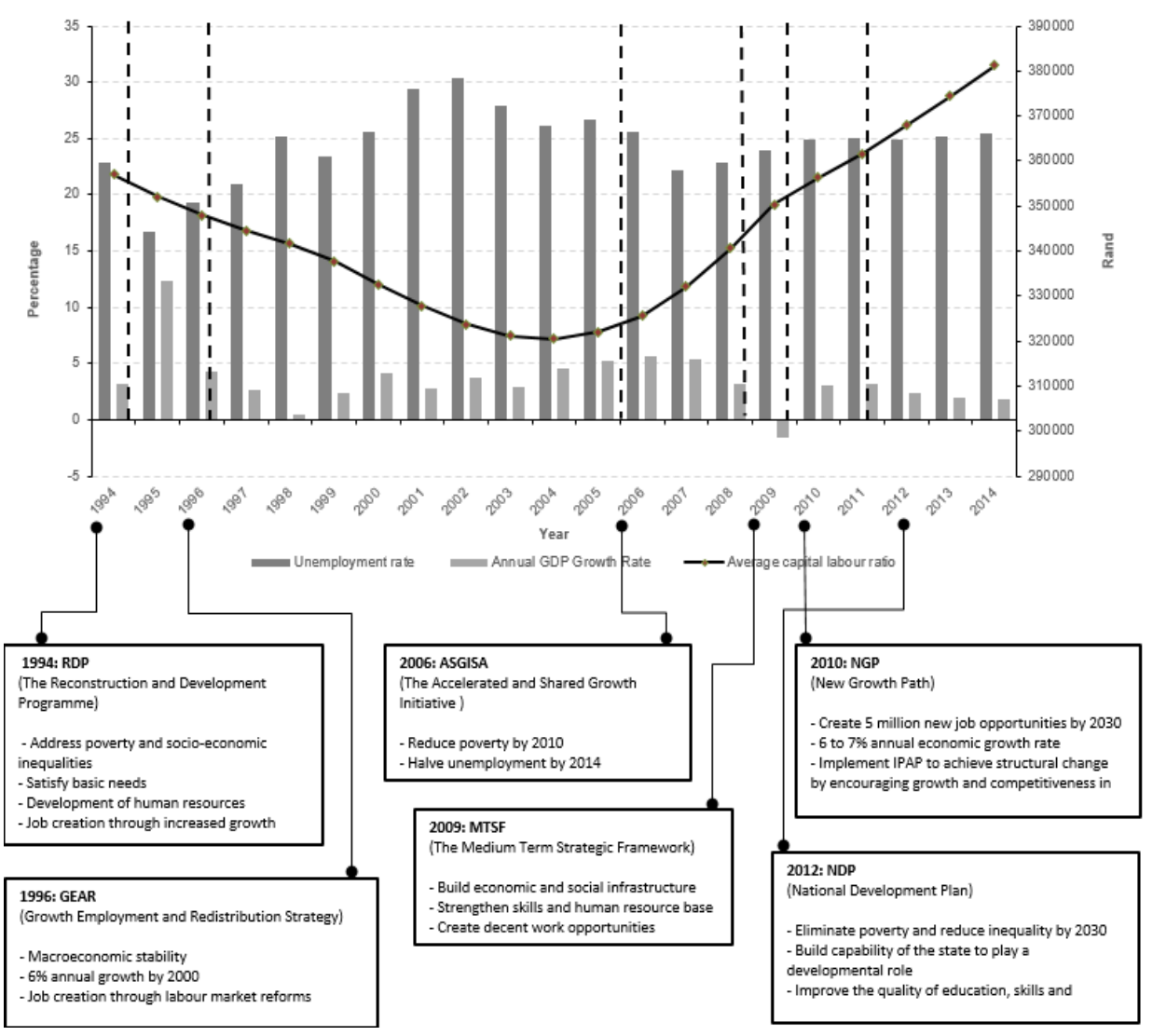

FIGURE 3: Unemployment rate, annual GDP and the average capital-to-labour ratio: 1994-2014

Source: $\quad$ SARB (2014) and StatsSA (2013b)

Note: According to the South African Reserve Bank, the average capital-to-labour ratio measures the ratio of capital employed relative to the labour employed.

\subsection{The CGE model}

The CGE model used in this paper is known as the PEKDGEM, a smaller and simpler version of the Industrial Development Corporation General Equilibrium Model (IDCGEM). The IDCGEM is a CGE model of the South African economy based on the well-documented Australian ORANI-F model (Horridge, Parmenter \& Pearson, 1993) and was developed in the early 1990s by the Industrial Development Corporation (IDC). It is a model of the economy in a single period, designed to determine the effect of policy changes on the economy during that period through comparative analysis (Naudé \& Coetzee, 2004). Whereas the IDCGEM contains 108 single product industries, two margin commodities, 65 categories of labour (four races plus migrant workers) and 24 households (races including six income levels) (Naudé \& Coetzee, 2004), the PEKDGEM has only 36 sectors and omits the regional dimension.

Since the focus of the modelling is on labour-related issues, some comments should be made about the modelling of labour in the PEKDGEM, as discussed in the study by Naudé and Coetzee (2004). 


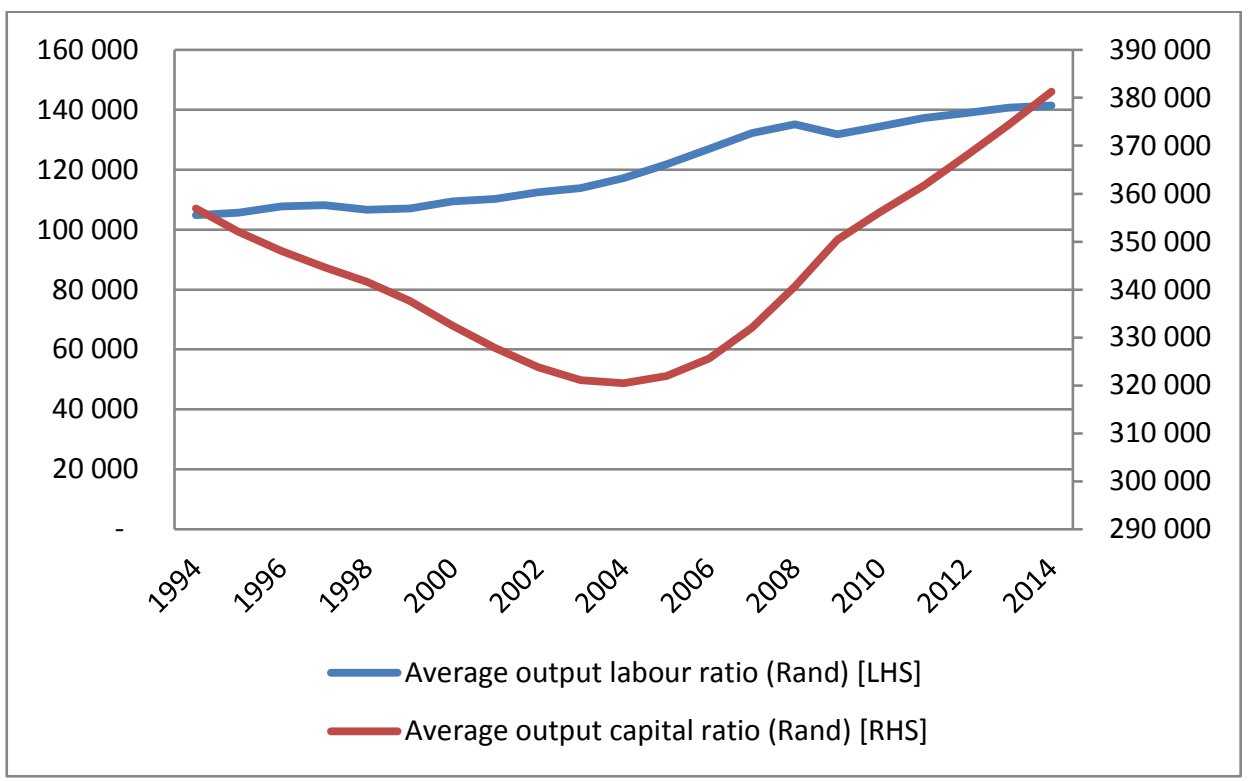

FIGURE 4: Average output-to-labour ratio vs. average output-to-capital ratio

Source: $S A R B$ (2015)

Firstly, the PEKDGEM decentralises the demand for labour according to race and occupation, which is in contrast to the demand for other primary factor inputs. The occupation-specific demand for labour is a function of the elasticity of substitution and the relative prices of occupation-specific labour. If there is a change in the relative wages of an occupation, substitution between the different occupations will take place. Therefore, for industries to minimise their total labour cost, they will choose various combinations of occupations in their workforce. Secondly, the PEKDGEM does not specify a labour supply function. This implies that the supply side cannot place any upward pressure on wages during unemployment (the absence of work shortages). Thirdly, wages are assumed to be flexible in the PEKDGEM and will adjust according to the closure related to the primary factor market. By adjusting the real wages exogenously, movements in the real wage rate can be incorporated. Finally, the results of the simulation are influenced by the manner in which the labour market specification is closed.

\subsection{The history-based closure and observed movements from 1995 to 2013}

To conduct the analysis of the South African economy during the period 1995-2013, a historical closure is applied to the PEKDGEM model. Included among the variables of the historical closure are observables and assignables. Assignable variables are naturally exogenous and can be assigned a value without contradicting anything that was assumed or observed in the historical period. What makes the historical closure somewhat different from other closures is that variables that would be considered naturally endogenous in policy modelling are set exogenously in their historically observed values. Therefore, various naturally exogenous variables must be allowed to move endogenously for the model to maintain its compatibility with the given parameter estimates and the observed values over the historical period (Bohlmann \& Breitenbach, 2013). 
The study uses a historical closure to quantify the effects of changes in the economy from 1995 to 2013. The historical closure includes exogenous variables, chosen to facilitate observations on movements in employment, investment, government spending, capital stocks, imports, exports and many other variables that are introduced to the model as shocks. The closure, which includes an input-output table that incorporates available statistics from 1995 to 2013, is concerned with the changes in unemployment under a review of the various economic policies implemented since 1994. The effect of the particular change is calculated by comparing the path of the policy simulation with the path of the baseline simulation.

\subsection{Observed movements from 1995 to 2013}

TABLE 1 shows the variables that were set as exogenous, indicating their observed annual movements based on available historical data from 1995 to 2013. TABLE 2 shows the same exogenous variables, represented as cumulative percentage changes away from the 1995 initial solution.

The literature has shown that South Africa has faced severe and persistent unemployment since 1994. This is the result not only of slow growth but also the pattern of the country's growth over the past 20 years. Putting the 2008/2009 recession aside, there have been significant improvements in South Africa's growth performance, and some job opportunities have been created. However, this has occurred at a very slow pace, making it difficult to argue that there has been a structural shift towards more labour-absorbing job creation. All the major national economic policy initiatives since 1994 have emphasised the problem of unemployment and slow growth, yet few successes have been recorded. This is evident in the endogenous macro variables in TABLE 1 . What is striking at first glance is the sharp decline in real GDP growth, the widening of the trade deficit (despite the weakening of the rand) and, finally, the increase in the use of capital relative to labour.

Apart from the main macro variables that were chosen, TABLES 1 and 2 also illustrate selected industry variables in the electricity and gold sectors. Both these sectors are of great importance to South Africa's economy and by combining available output and price data for these sectors, endogenously estimated shifts in demand and productivity can be estimated.

To determine whether South Africa's economic policies since 1994 have been successful in addressing the pressing issue of unemployment, reference is made to the detail in FIGURE 5, which illustrates movements in selected macro variables as cumulative percentage changes. FIGURE 5 gives a broad overview of the trends and movement in South Africa's labour market, based on the historical data set out in TABLE 1 .

FIGURE 5 shows movements in labour versus capital, and exports versus imports. The figure clearly illustrates the widening trade deficit and the impact of the global financial crisis in 2008/2009, together with the poor performance of the labour market regarding employment numbers compared with the growth in capital stock. TABLE 2 illustrates a cumulative percentage change of $62.7 \%$ for exports and $112.7 \%$ for imports from 1995 to 2013 . The growth in imports is thus almost double the growth in exports over the same period.

FIGURE 5 also shows the sharp increase in the capital-to-labour ratio, indicating an increase in the use of capital relative to labour. The following sections will show the movements in the variables that were determined endogenously in the PEKDGEM model and that will help to explain the observed movements illustrated in FIGURE 5. 


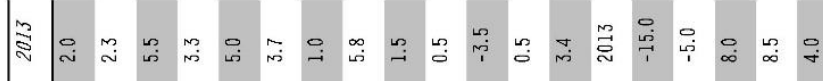

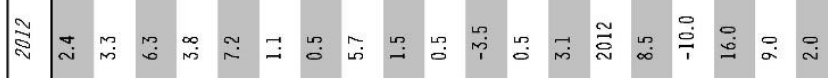

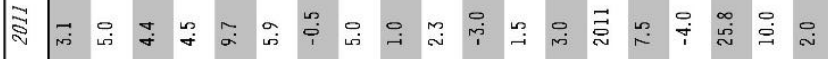

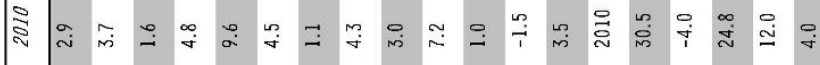
商

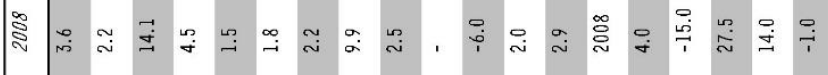

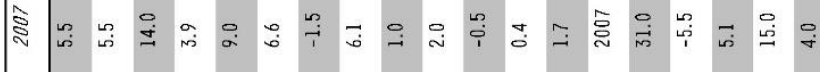
胥

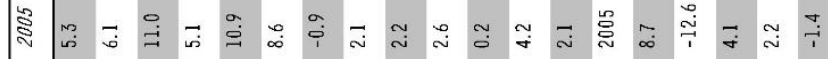

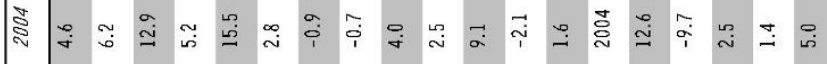

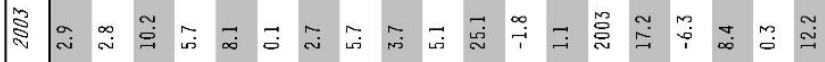

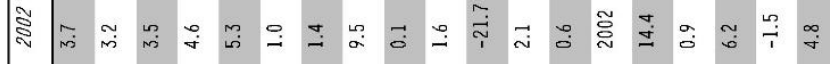

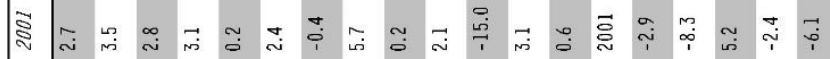

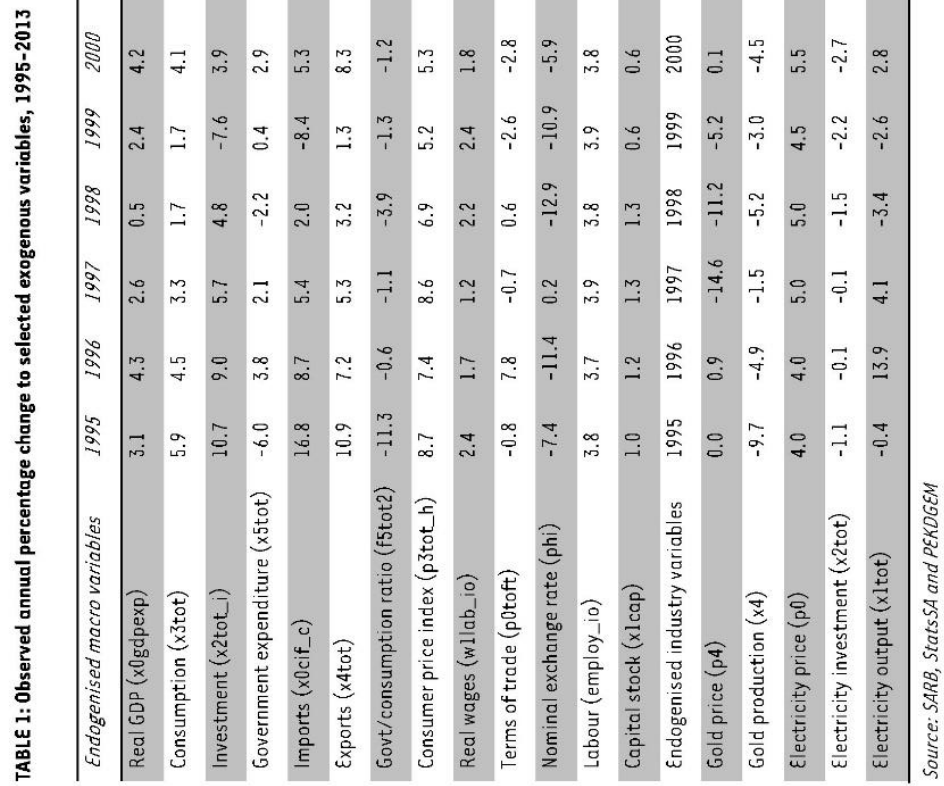




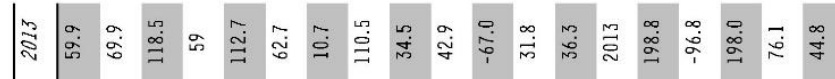

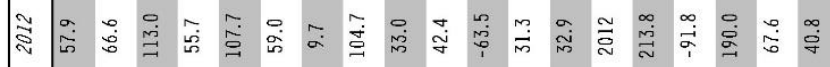
离岾

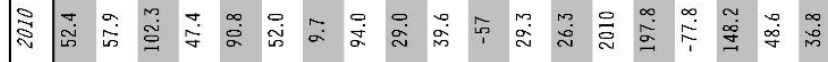

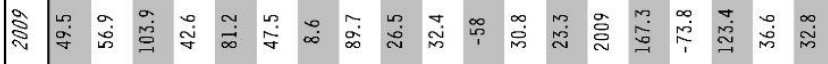

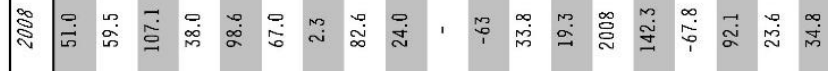

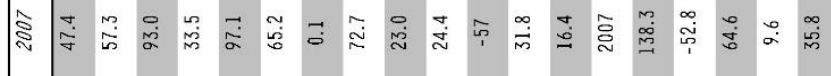

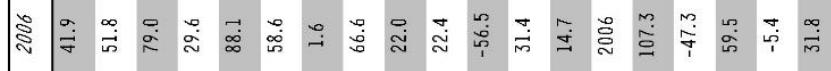

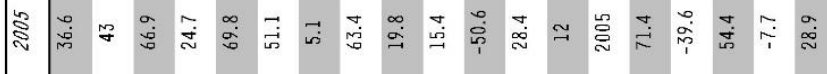

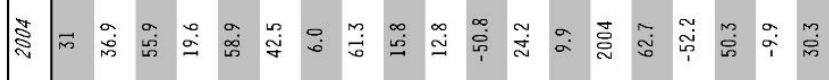

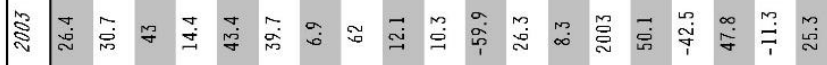

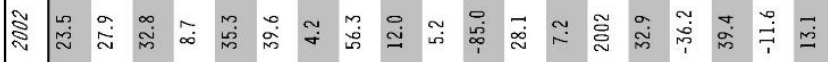

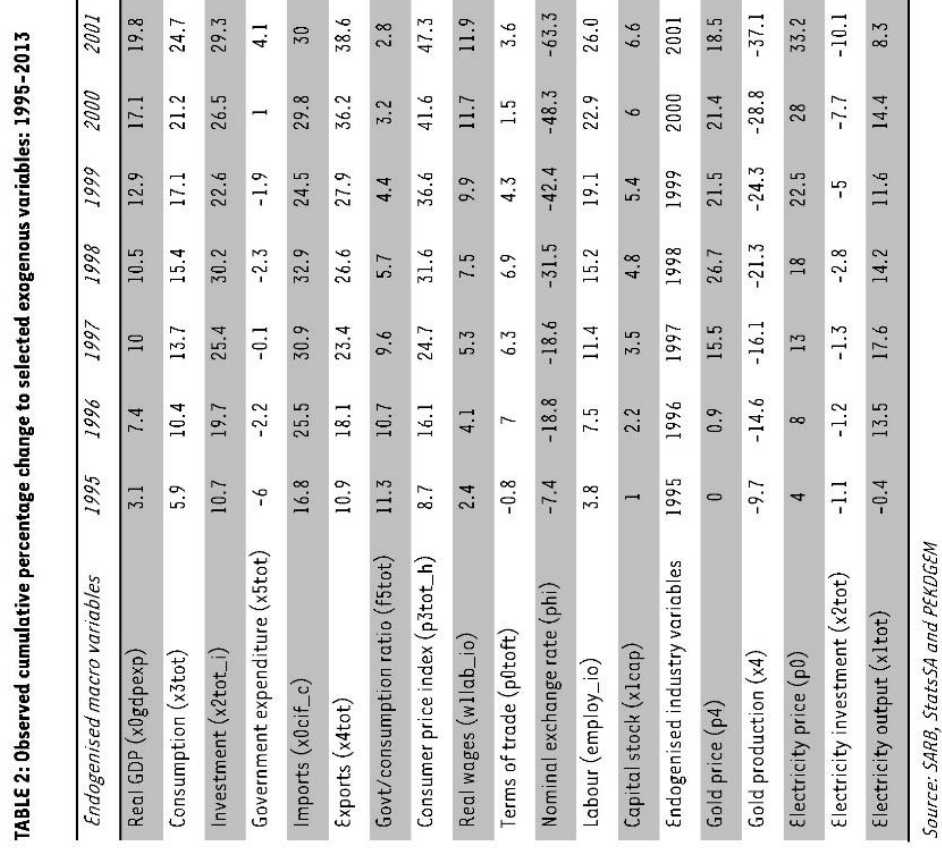




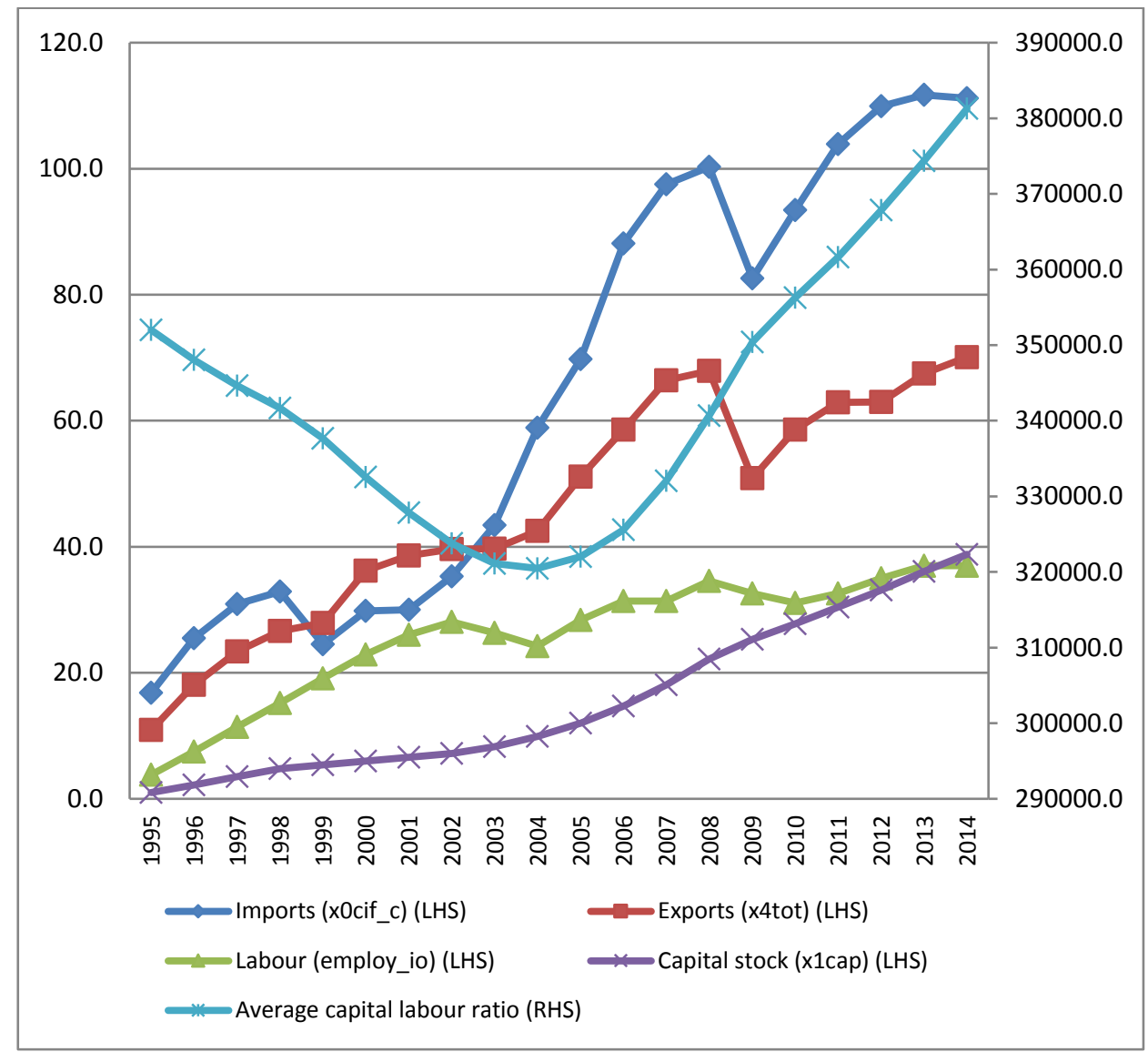

FIGURE 5: Cumulative percentage change to labour, capital and trade

Source: $\quad$ SARB, StatsSA

\section{HISTORICAL SIMULATION RESULTS FROM 1995 TO 2013}

The PEKDGEM model has determined the movement of various endogenously set variables, given the closure and historical exogenous shocks applied to the model. TABLES 3 and 4 show the endogenously determined variables most relevant to the analysis of the selected macro and industry variables in TABLE 1 . The macro variables include: aggregate employment (employ_io); average capital rental (plcap_i); average real wage (avewager); balance of trade (delB); the shift in export demand ( $\left.f 4 q_{-} c\right)$; and total government expenditure (wgovexp). The industry variables chosen are employment by industry (wmploy_o), which includes trade, community services, manufacturing, mining and agriculture. TABLE 3 shows the results as annual percentage changes, while TABLE 4 shows them as cumulative percentage changes. 


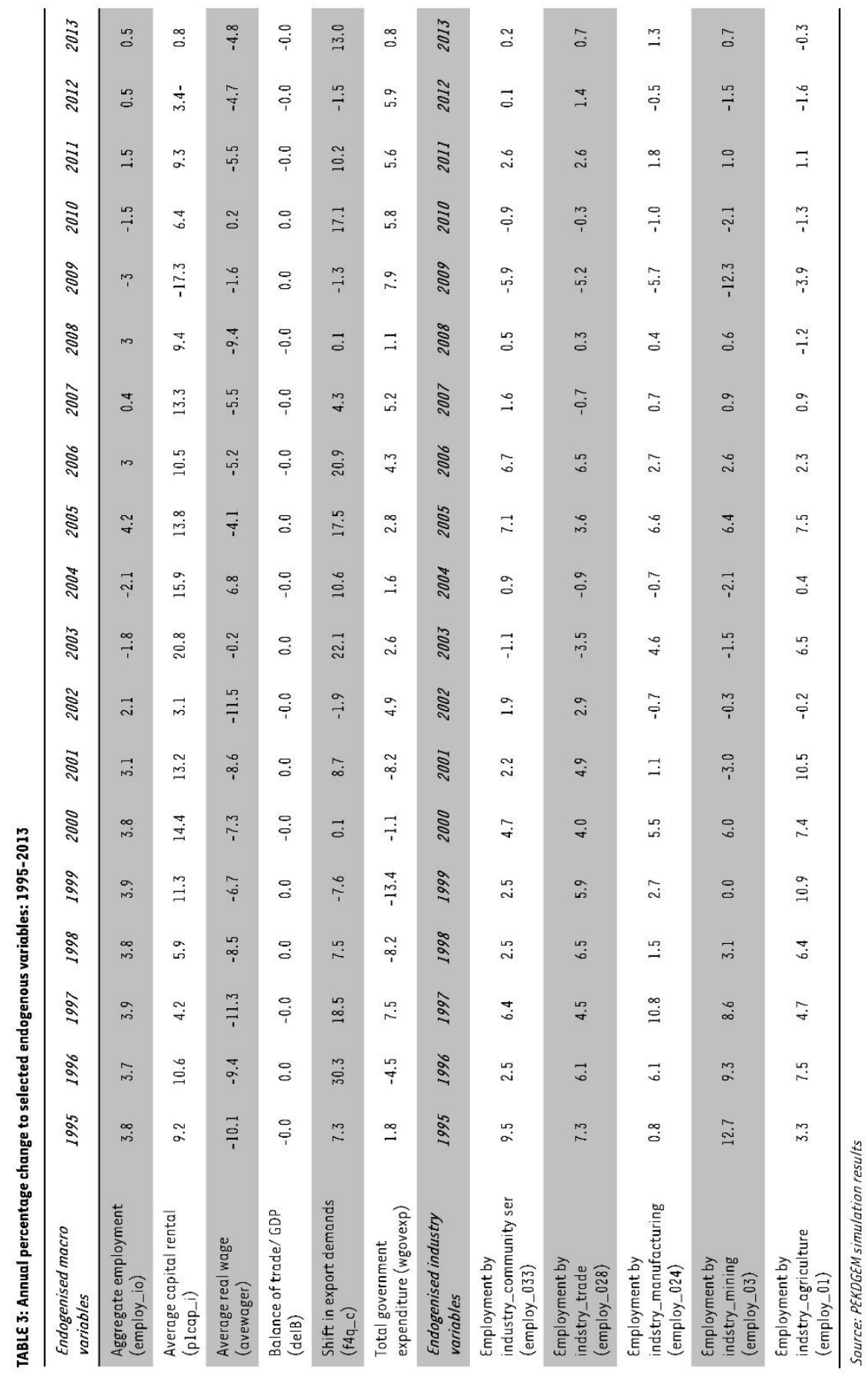




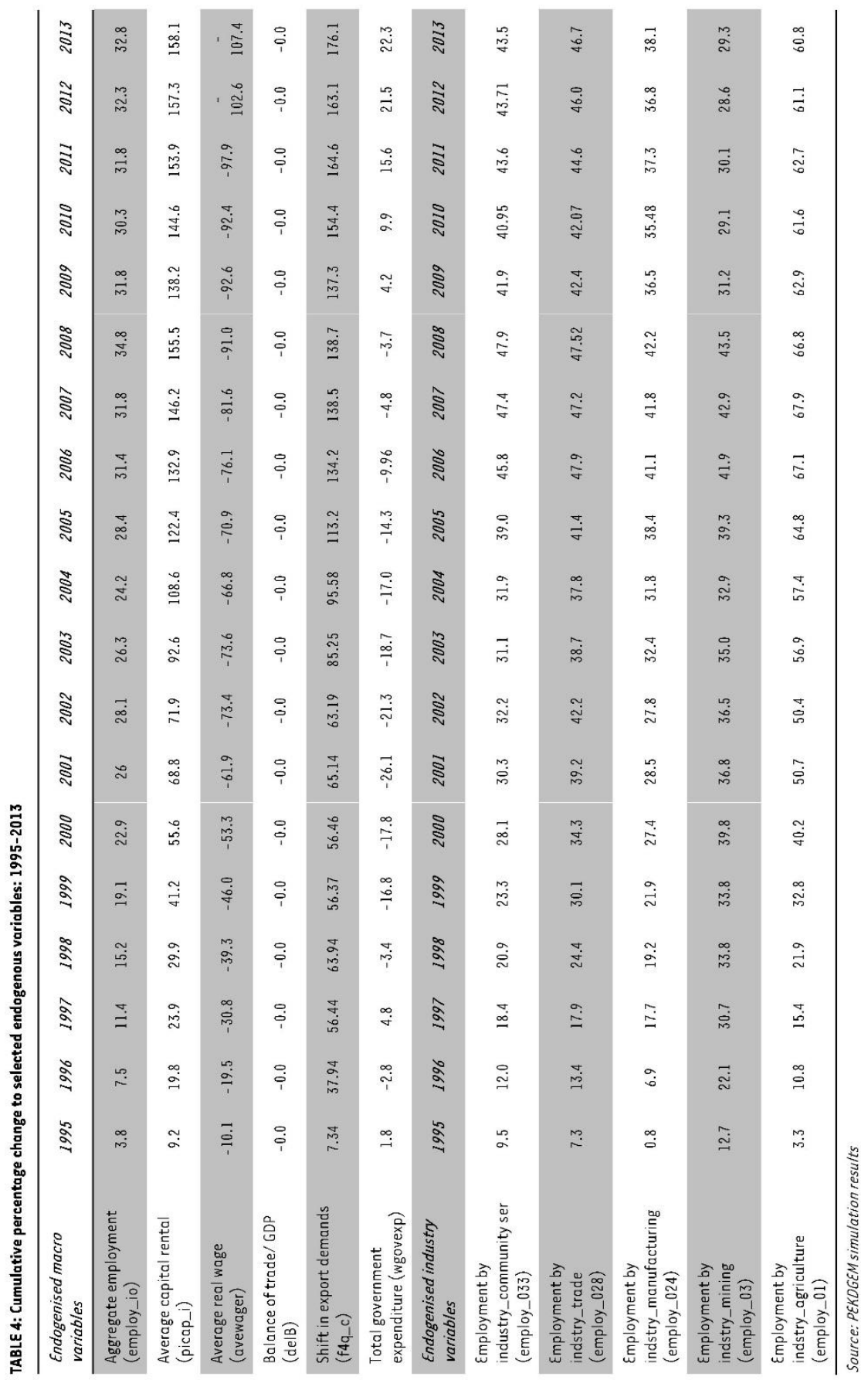


The most noticeable result from the historical simulations, and also the core focus of the analysis, is the changes observed in the primary factor alignment, i.e. the combination of capital and labour. The historical data in TABLE 1 shows an increase in capital relative to labour $(\mathrm{K} / \mathrm{L})$ during the 1995-2013 period, despite an observed increase in the rental of capital relative to wages $\left(P_{k} / P_{L}\right)$. This seems to defy the conventional theory of employment. The industry variables support this finding and show that the structure of employment by industry has shifted substantially.

\subsection{Macroeconomic effects}

The literature reveals that the main quantitative objectives built into the country's post-1994 economic policies include generating an annual growth rate of $6-7 \%$, halving unemployment and poverty by 2014 , and making South Africa's productive sectors the largest employers. The general assessment of these policies, though, is that they are not breakthrough policies capable of promoting increased growth and employment. Each new policy has hardly differed from the previous one and has prompted a laid-back approach to addressing South Africa's many socioeconomic challenges.

These shortcomings and failures are vividly apparent in TABLE 3, which gives a macroeconomic overview of the economy since South Africa became a democracy in 1994. Although employment growth remained steady from 1995 to 2002, it started to decline in 2003 and worsened due to the 2008/2009 global financial crisis. The balance of trade was relatively constant from 1994 to 2001. It was only in 2002 that imports started to outpace exports (as also seen in TABLE 1), resulting in an overall trade deficit. When South Africa experienced a constant balance of trade during the 1990 s, there was slow but consistent growth in employment, and vice versa, when imports started to grow faster than exports.

Even though the economy has been experiencing trade deficits in recent years, the shift in export demand has varied over the past two decades. Export demand for locally produced goods is subject to input cost, which means capital and labour. Looking at the cost of labour and capital in TABLE 3, one can see some consistency between the shift in export demand and the price of inputs. The gradual decrease in the demand for exports as imports have grown, together with increases in the price of labour, has resulted in a decline in employment growth.

This is in line with the finding in the literature that, firstly, the net effect of employment in the trade sector is small and that, secondly, the employment gains appear to be larger for skilled labour than for semi-skilled and unskilled labour. Lastly, the changing trade orientation in South Africa over the past two decades seems to be towards capital rather than labour (Gossel \& Biekpe, 2014). This is not consistent with the theory that producers will choose the most cost-effective combination of inputs for production, seeing as the cumulative percentage change in the average capital rental is $158.1 \%$ compared to the $-107.4 \%$ for the average real wage of labour from 1995 to 2013.

Finally, the analysis considered total government expenditure. The government undertakes various expenditures to carry out key functions in the economy, including job creation. Since 1995, government spending has fluctuated but has shown a small overall increase, with a cumulative percentage change of $22.3 \%$. This has contributed to the slow growth in employment. 


\subsection{Industry-level effects}

In addition to the overall macroeconomic impact on employment, the exogenous shocks applied had a significant impact on employment levels across different sectors. For the purpose of this analysis, the trade, community services, mining, manufacturing and agricultural sectors were chosen to determine how employment changed.

From the industry-level results shown in TABLE 3, it is clear that from 1995 to 2013, South Africa's structure of employment by industry shifted substantially. The first indication is the overall increase in employment in the community services sector since 1995, with new job opportunities primarily being in education, healthcare and the police force (Statistics South Africa, 2013a). However, the increase in government spending on labour-intensive projects has also contributed to employment growth in the community services sector.

The results also show rising employment rates in the trade sector, which includes wholesale and retail. Changes in the trade sector have mostly been driven by internationalisation and rising competition, which have transformed the way that businesses operate and the types of jobs for which there is a demand (Van Aardt et al., 2011). South Africa's wholesale and retail sector is regarded as a major employer and a critical source of growth for the economy. However, to ensure the sector's competitiveness and contribution to economic growth, these sectors have necessarily become more skills-intensive (Van Aardt et al., 2011).

In contrast, main productive sectors such as manufacturing and mining experienced much slower growth in employment and a decline as a percentage of total employment over the same period. The agricultural sector also showed an overall decrease in employment since 1994. However, this sector remains one of the country's largest employers, especially in rural and underdeveloped areas. Mining and agriculture represent two of the most labour-intensive sectors in South Africa, yet there has been a sharp decline in employment due to structural changes taking place in various industries since 1994 .

According to the objectives of the NGP and the IPAP, the manufacturing, mining and agriculture sectors should be the largest contributors to employment growth - not the services sector. Yet these two economic policy documents also reveal that South Africa's productive sectors have been contributing far less than they are capable of (DTI, 2013). When South Africa became a democracy in 1994, the aim was to accelerate economic growth and stimulate many more employment opportunities. Linked to this was the quest to restructure the manufacturing sector in order to make the economy more competitive in the international arena. However, the results show that the hoped-for changes have not been realised.

This brief overview of the simulation results of the macro and industry variables clearly indicates how the reality differs from the theory of growth and employment. With structural change having played a significant role in South Africa's high unemployment rate since 1994, such change namely the preference for capital over labour - needs to be addressed.

\subsection{The observed capital-to-labour changes}

Based on the simulation results broadly discussed in the previous sections, it can be concluded that there has been a technical change in favour of capital relative to labour from 1995 to 2013.

According to the Heckscher-Ohlin theory, South Africa has a comparative advantage in unskilled labour-intensive goods - which is not surprising given the country's abundance of labour and high 
levels of unemployment. The theory predicts that liberalising trade would lead to an increase in the demand for unskilled labour, which would ultimately result in a decrease in income inequality and poverty. Unfortunately, this has not been the case for South Africa. In terms of the results, there has undeniably been an improvement in trade (imports and exports) following the opening of the economy to global markets. While this is in line with predicted theory, the accompanying increase in employment and reduced income inequality and poverty have not materialised.

In addition, the increase in capital intensity has lowered the need for unskilled and low-skilled labour and increased the demand for skilled labour to operate and maintain capital equipment. This could explain the substantial decrease in South Africa's aggregate employment from 1995 to 2013.

To standardise the increase in the $\mathrm{K} / \mathrm{L}$ ratio, a cost-neutral capital/labour preference is introduced, named 'twistlab'. The capital/labour preference variable (twistlab) captures the changes between capital and labour that are not explained by the relative price changes in these variables.

The results over the 1995 to 2013 period indicate a strong shift in the preferences away from the use of labour to capital. To better understand the structural change, the theoretical specification of the capital/labour preference within PEKDGEM is considered. The input demand equations of industries are determined subject to a CES (constant elasticity of substitution) combination function with substitution elasticities $(\sigma)$ between the various primary sectors, set at 0.2 . With $\sigma \neq 1$ in the input demand equations, it allows the capital/labour preference variable to accommodate the exogenous historical data to be introduced and converted into taste or technical changes (adjustments to the PEKDGEM equations were made based on the work of Bohlmann and Breitenbach (2013)).

The historical simulation results using PEKDGEM show a strong technical change in favour of capital relative to labour between 1995 and 2013 . This is displayed in the positive value of $8.1 \%$ generated for the capital-labour preference.

The results suggest that, at any given ratio of real wages relative to the rental price of capital, industries would choose a $\mathrm{K} / \mathrm{L}$ ratio of $8.1 \%$ higher in 2013 than in 1995. With more capital preferred relative to labour in the production process, this can also be interpreted as a change in the preferences of industries in terms of how their production composition should look. In recent years, there have been some industrial action cases, together with labourers going on strike to push for higher real wages. However, according to Altman (2001), South African industries depend on low wages to remain competitive in global markets. As a result, more and more industries have started to invest in capital, rather than labour, to stay competitive.

\section{CONCLUSION}

When comparing the employment-related objectives embodied in the various economic policy documents rolled out in South Africa after 1994 with what has actually transpired on the job front, it becomes clear that the policies have not delivered on their intentions. Not only has there been a decline in employment growth over the past two decades, but there has also been a structural shift in the economy towards a preference, among industries and employers, for capital over labour. This is reinforced in the literature by Edwards (2001), Bosworth and Collins (2003), and Banerjee et al. (2008), who all found that many skilled sectors in South Africa are having difficulty filling certain positions in the face of the structural nature of South Africa's unemployment. 
Furthermore, Banerjee et al. (2008) indicate that there have been sectoral changes in unemployment, attributable to a structural shift in production away from the employmentintensive primary sector to the tertiary sector. This has resulted in a decrease in the demand for labour, particularly unskilled labour.

The results of the historical CGE analysis suggest that at any given ratio of real wages relative to the rental price of capital, industries would choose a K/L ratio of $8.1 \%$ higher in 2013 than in 1995. This shows that there is little alignment between the desired outcomes of the country's economic policies and what has eventuated during the post-1994 period.

South Africa has a comparative advantage in unskilled labour-intensive goods - helped by the country's abundance of labour and high levels of unemployment - but the true drivers of competitiveness and sustainable growth should be capital-intensive and innovation-rich production processes. This highlights the failure of South Africa's economic policies to pinpoint and tackle the causes of the country's escalating unemployment phenomenon. According to Aron et al. (2008), the government needs to increase the employment intensity of the economy by reducing the skill mismatch. In this regard, policy interventions may include a more vocational approach to education, training incentives, government-funded programmes aimed at building entrepreneurial skills and opening up the employment space in the public and private sectors, and job search assistance. An urgent requirement, too, is the reform of labour legislation, so that greater worker throughput is encouraged and productivity is rewarded.

There is no quick or obvious solution to South Africa's unemployment woes. Just as problems take time to manifest, so remedies take time to be implemented and to start generating results. What is clear, however, is that having the right economic policy framework in place - which is the result of proper analysis and consultation - is crucial. This paper has lifted the lid on the apparent inability of South Africa's economic policy to properly address the most serious challenge facing the country - unemployment. While the government might be the official custodian of economy policy, the economy as a whole belongs to everyone. With a view to the future, therefore, it is essential that stakeholders from across the broad economic spectrum take stock of what is really impeding the country's economic progress and, together, commit to putting the country onto a new path that will take a much larger slice of the population into a more productive and satisfying future.

\section{LIST OF REFERENCES}

Adams, A.V., Da Silva, S.J. \& Razamara, S. (2013). Improving skills development in the informal sector: Strategies for Sub-Saharan Africa. Available:

http://dx.doi.org/10.1596/9780821399682_CH01. (Accessed 12 August 2014).

Altman, M. (2001). Paths to employment expansion in a minerals economy. Urban Forum, 12(3-4), July-December, Special issue: WORK 2001, First International Conference on Employment Creation in Development, p. 314.

Altman, M. \& Mayer, M. (2003). Overview of industrial policy. Human Resource Development Review 2003: Education, Employment and Skills in South Africa. HSRC, Cape Town: HSRC Press.

Aron, J., Kahn, B. \& Kingdon, G. (2008). South African economic policy under democracy: Overviews and prospects. In Aron, J., Kahn, B. \& Kingdon, G. (eds.) South African Economic Policy under Democracy. Oxford: Oxford University Press. 
Banerjee, A., Galiani, S., Levinsohn, J., McLaren, Z. \& Woolard, I. (2008). Why has unemployment risen in the new South Africa? Economics of Transition, 16(4), pp. 715-740.

Bell, T. \& Gattaneo, N. (1997). Foreign trade and employment in South African manufacturing industry. Occasional report no 4. Geneva: Employment and Training Department, ILO.

Bhorat, H. \& Hodge, J. (1999). Decomposing shifts in labour demand in South Africa. South African Journal of Economics, 67(3), pp. 348-380.

Bhorat, H., Lundall, P. \& Rospabe, S. (2002). The South African labour market in economic and legislative considerations. IL0 Employment Paper 2002/32, Geneva.

Black, P., Calitz, E. \& Steenekamp, T. (2011). Public Economics. $5^{\text {th }}$ edition. Goodwood, Cape Town: Oxford University Press South Africa.

Bohlmann, H.R. \& Breitenbach, M.C. (2013). A historical CGE analysis of the South African economy from 2007-2013. Paper presented at the ESSA 2013 Conference, September, Bloemfontein.

Bosworth, B. \& Collins, S.M. (2003). The empirics of growth: An update. Brookings Papers on Economic Activity, 34(2), pp. 113-206.

Burger, R. \& Woolard, I. (2005). The state of the labour market in South Africa after the first decade of democracy. Centre for Social Science Research, Working Paper, no 133. Cape Town: Southern African Labour \& Development Research Unit.

Dixon, P.B. \& Rimmer, M.T. (2002). Dynamic General Equilibrium modelling for forecasting and policy: A practical guide and documentation of MONASH. Amsterdam: North-Holland.

DTI (Department of Trade and Industry). (2002). Accelerating growth and development: The contribution of an integrated manufacturing strategy. Pretoria: Government Printer.

Du Plessis, S.A. \& Smit, B. (2007). South Africa's growth revival after 1994. Stellenbosch Economic Working Paper, $1 / 2006$.

Edwards, L. (2001). Globalisation and the skills bias of occupational employment in South Africa. The South African Journal of Economics, 69(1), pp. 40-72.

Fedderke, J. \& Bogetic, Z. (2006). Infrastructure and growth in South Africa: direct and indirect productivity impacts of 19 infrastructure measures. World Bank Policy Research Working Paper No. 3989. Available: http://ssrn.com/abstract=926442. (Accessed 10 July 2014).

Fields, G. \& Kanbur, R. (2007). Minimum wages and poverty with income sharing. ILR Collection, Cornell University.

Fourie, F.C v N. (2013). The NDP on unemployment: On consistency, coherence and comprehensiveness. Paper presented at the ESSA Conference, September, Bloemfontein.

Fox, L. \& Sekkel, M. (2008). Working out of poverty: Job creation in Africa. Poverty in Focus, 16: 'Jobs, Jobs, Jobs: The Policy Challenge'.

Gossel, J. \& Biekpe, N. (2014). Economic growth, trade and capital flows: A causal analysis of postliberalised South Africa. The Journal of International Trade \& Economic Development, 23(6), pp. 815836.

Herwartz, H. \& Niebuhr, A. (2011). Growth, unemployment and labour market institutions: evidence from a cross-section of $\varepsilon U$ regions. Applied Economics, 43(30), pp. 4663-76.

Hirsch, A. (2005). Seasons of hope: Economic reform under Mandela and Mbeki. South Africa: UKZN Press \& IDRC. 
Hodge, D.C. (2009). Growth, employment and unemployment in South Africa. South African Journal of Economics, 77(4), pp. 488-504.

Horridge, J.M., Parmenter, B.R. \& Pearson, K.R. (1993). ORANI-F: A general equilibrium model of the Australian economy. Economic and Financial Computing, 3(2), pp. 71-172.

IMF (International Monetary Fund). (2013). South Africa searches for faster growth, more jobs. Available: http://www.imf.org/external/pubs/ft/survey/so/2013/car080713a.htm. (Accessed 22 February 2014).

Kapsos, S. (2005). The employment intensity of growth: Trends and macroeconomic determinants. Employment Strategy Papers, International Labour Office.

Kingdon, G. \& J. Knight. (2008). Unemployment in South Africa 1995-2003: Causes, Problems and Policies. Journal of African Economies, 16(5), pp. 813-848.

Klasen, S. \& Woolard, I. (2009). Surviving unemployment without state support: Unemployment and household formation in South Africa. Journal of African Economies, 18(1), pp. 1-51.

Lavopa, A. \& Szirmai, A. (2012). Manufacturing growth, manufacturing exports and economic development 1960-2010. 14 $4^{\text {th }}$ ISEE Conference, Brisbane. Available: http://www.aomevents.com/media/files/ISS\%202012/ISS\%20SEssion\%209/Lavopa\%281 \%29.pdf. (Accessed 25 June 2015).

Lewis, J.D. (2002). Promoting growth and employment in South Africa. South African Journal of Economics, 70(4), pp. 647-687.

Lingens, J. (2003). The impact of a unionised labour market in a Schumpeterian growth model. Labour Economics, 10(1), pp. 91-104.

Lyle, F., Kasongo, A., Moses, M. \& Yu, D. (2015). The South African labour market, 1995-2013. ERSA Working Paper 493, Economic Research Southern Africa (ERSA).

Maloney, W. (2002). Informality revisited. Mimeo. Washington: World Bank.

MERG. (1993). Making democracy work: A framework for macroeconomic policy in South Africa. Cape Town: OUP.

Naudé, W. \& Coetzee, R. (2004). Globalisation and inequality in South Africa: modelling the labour market transmission. Journal of Policy Modeling, 26(2004), pp. 911-925.

Ocran, M.K. (2009). Fiscal Policy and Economic Growth in South Africa. Paper presented at the Centre for the Study of African Economies, 22-24 March, Oxford University, UK.

Oosthuizen, M. (2006). The post-apartheid labour market: 1995-2004. DPRU Working Paper 06/103. Cape Town: Development Policy Research Unit, University of Cape Town.

South Africa. Department of Trade and Industry (DTI). (2013). Industrial Policy Action Plan 2013/142015/16. Pretoria: Government Printer.

South Africa. Economic Development Department. (2011). The New Growth Path: Framework. Pretoria: Government Printer.

South Africa. Economic Development Department. (2012). National Development Plan 2030: Our future-make it work. Pretoria: Government Printer.

South African Reserve Bank (SARB). (2014). Series on deficit as a percentage of GDP (KBP4420F). Available: http://www.resbank.co.za/research/statistics/pages/onlinedownloadfacility.aspx. (Accessed 25 May 2014). 
Staatz, J. \& Dembele, N.N. (2007). Agriculture for Development in Sub-Saharan Africa. Background paper for the WDR2008.

Statistics South Africa. (1995). Labour Force Survey, 1995.

Statistics South Africa. (2002). Labour Force Survey, 2002.

Statistics South Africa. (2011). Financial statistics of consolidated general Government 2009/2010. Available: http://wwwstatssa.gov.za/publications/P9119.4.pdf. (Accessed 27 February 2014).

Statistics South Africa (SSA). (2013a). Statistical release P3041.2. Manufacturing: Production and Sales. December 2012. Pretoria: Statistics South Africa.

Statistics South Africa (SSA). (2013b). Statistical release P0211. Quarterly Labour Force Survey. Quarter 1 2013. Pretoria: Statistics South Africa.

Statistics South Africa. (2013c). GDP data for third quarter 2013. Pretoria: Statistics South Africa.

Statistics South Africa. (2013d). Work \& labour force. Pretoria: Statistics South Africa.

Van der Berg, S. (2006). Public spending and the poor since the transition to democracy in poverty and policy in post-apartheid South Africa. Cape Town: Human Science Research Council (HSRC) Press.

Van Aardt, C.J., Ligthelm, A.A. \& Van Tonder, J. (2011). A broad review of the New Growth Path Framework with a specific emphasis on the feasibility of its proposed targets. Available: http://www.unisa.co.za/contents/faculties/ems/docs/press413.pdf. (Accessed 23 June 2014).

Visser, W. (2004). Shifting RDP into GEAR: The ANC Government's dilemma in providing an equitable system of social security for the 'new South Africa'. Paper presented at the $40^{\text {th }}$ ITH Linzer Conference, 17 September 2004.

Yu, D. (2008). The South African labour market, 1995-2006. Stellenbosch Economic Working Paper 05. Stellenbosch: Stellenbosch University. 